\title{
Ethical and legal aspects of disaster response under Indonesian legal system
}

\author{
Ida Susanti ${ }^{1, *}$ \\ ${ }^{1}$ Centre for Adaptation and Resilience Environmental Design Studies, Parahyangan Catholic University (Faculty of Law), Jl. \\ Ciumbuleuit No. 94 Bandung, 40141, Indonesia
}

\begin{abstract}
Indonesia is a vulnerable country to disasters. Because almost all islands in Indonesia has the volcanoes, Indonesia is in the ring of fire, which potentially triggers a volcano eruption disaster. Moreover, earthquake, flood, tsunami, landslides regularly occur in Indonesia. It is very important to the response to such disasters. Recently, many regulations have been issued by the government, yet many unjust or indecent treatment have been experienced by displaced persons or the victims of disasters. Some illustrations concerning how bad legal position of disasters' victims, especially their private rights, will be explored. It is common that in a contract, a natural disaster will be considered as a force majeure. A legal consequence of this condition is, the disasters' victims must defray or restore the damage by themselves. It could be very unfair or inhumane because, after the disaster usually, many victims lose their capacity to perform their previous legal obligation. In this issue, the law fails to protect, because legal solution could be formally legitimate but substantially unfair. In this case, ethical consideration must be endorsed, for increasing their capacity to recover from the disaster. This paper describes disaster responses in Indonesian's legal system, especially in the context to protect displaced persons or victims of disasters; and to explore justification to use legal ethics to protect them, in case legal protection fails to provide substantive justice for disasters' victims.
\end{abstract}

\section{Introduction}

Indonesia is a vulnerable country to disasters. As a country in the ring of fire, this country must be alert to the risk of volcanoes eruption. Indonesia is also located between two tectonic plates, i.e. the Indian/Australian plate, and the Eurasian plate. Potential earthquakes must be anticipated every time. Other disasters such as landslide, flood, forest fire, and tsunami happen often in Indonesia. During the disasters, two aspects must be responded, i.e. physical and social aspects. Because of the disaster, many infrastructures could be destroyed. Many people must be displaced for their safety, sometimes their location is too close to the center of the disaster, sometimes they have no shelter to live because the disaster had ruined their settlement. During that displacement, there are many issues must be anticipated. Lack of good infrastructures and facilities can create many problems, such as health problems of displaced persons, education of the children, mental disorder of the victims. Studying the details of past disasters, hazards or crises can help to provide valuable information to reduce vulnerability and to enhance the resilience of individuals, families, and communities [1].

This paper explores some impacts of the disaster, and how does such disaster may be responded. In many cases, victims of the disaster have been badly hampered by after effect of the disaster. Furthermore, legal protection cannot reach them. Thus, they cannot even access any preferential treatment, which should be addressed to any unfortunate citizen, such as the disaster victims. The question is, should we let the victims hardly or barely or slowly recover from their doomed condition? This paper will focus to analyze private law aspect of the natural disaster, especially what is the effect of the natural disaster to any contractual relationship that has been previously agreed by the victims of such the disaster.

The disaster relief would not be possible to be initiated by the victims themselves. Therefore, these following issues will be analyzed in the following parts of this paper:

a. How does the Indonesian legal system protect disaster victims?

b. How are contractual obligations affected by the disaster? Will the obligations remain, or will it be eliminated?

c. When the Indonesian legal system fails to provide any protection, is there any other possibility to safeguard victims' interest?

For answering those questions, the author will study "Ethical and Legal Aspects of Disaster Response under Indonesian Legal System".

Corresponding author: idasusantimg@yahoo.com 
The research method that will be employed by the author is a doctrinal legal research, which concerns with the formulation of legal 'doctrines' through the analysis of legal rules.[2] This method can be described as this specific figure(Fig. 1):

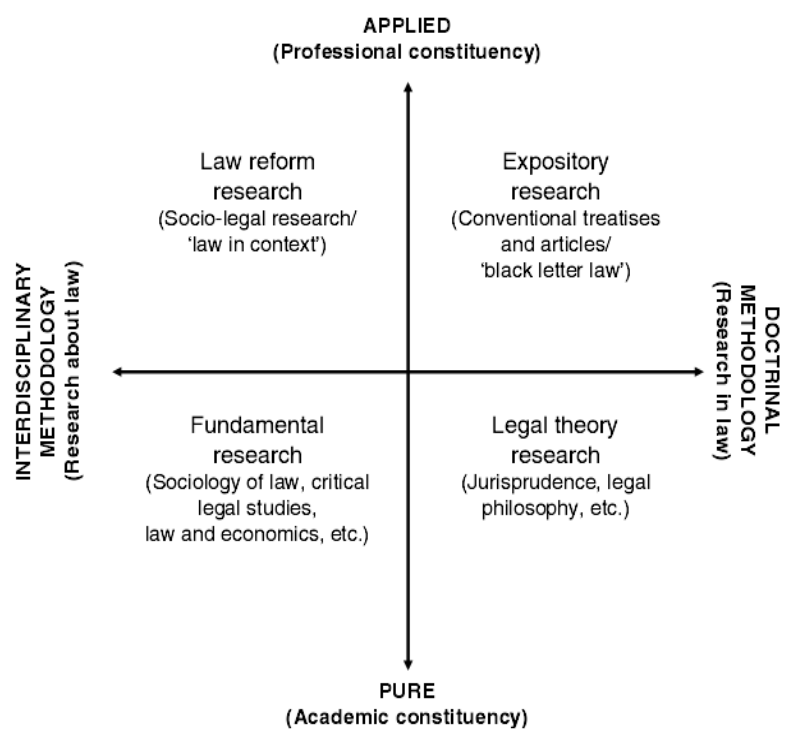

Fig. 1. Legal research style [3]

The doctrinal legal research in this paper will focus on finding and determining applicable rules in disaster management, which make the existence of the legal doctrines helpful to tackle natural disaster's problems. These systematic constructions can clarify any ambiguity within rules concerning disaster management. They can put those legal aspects, rules, and provisions related to disaster management in a logical and coherent structure. This method will study legal documents and it is also called the normative method.[4]

It will analyze Indonesia's regulations and court decisions, which indicate legal protection for the disaster victims. Furthermore, some ethical principles will be scrutinized, especially for understanding how those ethical principles should play a role when the legal system cannot provide fair and justice solutions.

\section{Protection for disaster victims under Indonesian legal system}

Disaster management in Indonesia has been regulated in Law No. 24 the year 2007 concerning Disaster Management (later it will be addressed as the Disaster Management Law). Based on the general terminology at that Law, the disaster is defined as 'an event or series of events that threatens and disrupts live and livelihoods, caused either by natural or non-natural and man-made factors, which produce death, environmental damage, loss of assets, and psychological impact.' This definition is very broad because it covers all occurrences that distract the life of human beings and ruin their properties. Furthermore, the natural disaster is 'event or series of event that threatens and disrupt lives and livelihoods, caused by disaster set off by natural event or series of events and includes earthquakes, tsunamis, volcanic eruptions, floods, droughts, hurricanes, and landslides.' The last landslide in Brebes, Central Java in February 2018 is an example of a natural disaster. Those occurrences have happened beyond the control of the victims as well as anyone else. That is happened because of unavoidable hazard, which creates negative effects to human beings and their assets. Furthermore, non-natural disaster is happened because of technology and modernism failures, or because of the epidemic outbreak (such as the leak of the nuclear reactor); while the social disaster is happened because of social conflict among social groups or social communities or terrorism (such as Bali bombing in 2002).

Article 3 of the Disaster Management Law manages the disaster based on humanity; justice; equality before the law and government; balance, harmony, and synchronicity; order and legal certainty; the sense of community; environmental conservation and science \& technology. Article 3 basically secures nondiscrimination treatment for the victims of a disaster. Based on its article, every disaster victim must have equal access to any legal protection, which has been regulated at that Law. Furthermore, the disaster management must be done quickly on target; based on priority; based on coordination and cohesiveness; based on efficiency and effectiveness; based on transparency and accountability; based on partnership, empowerment, non-discrimination, and non-proselytization. Those principles must be applied to all levels of disaster management phases because disaster must be responded distinctively based on the characteristic of each phase.

Article 26 paragraph (2) of this Law emphasizes the rights of disaster victims to get their basic needs. Furthermore, paragraph (3) of this article determined that if the disaster is happened because of construction failure, the victims entitled to receive damages. This article shows that disaster victims are acknowledged as specific part of the community who needs specific assistance, because during the disaster they do not have sufficient capacity to provide themselves, even for their basic needs. Therefore, they entitled to receive assistance or financial damages. It is unavoidable that the government must provide the national and regional budget for affording the cost of disaster relief.

The disaster aid management and budgeting must be effective, efficient, and accountable [5]. That budget will include fast response budget that could be used by the Board of Regional Disaster Management to counter any detrimental effect of disasters. It shows that when a disaster occurs, providing the cost of disaster relief is part of the government responsibilities.

In the context of safety and security, the police officers are commanded to firstly establish a Field Control Force, before the National / Regional Board of Disaster Management responses the disaster. After the National / Regional Board of Disaster Management has established such the Force, it will become the coordinator of disaster responses [6]. The Field Control Force will provide a daily report concerning the disaster management, disseminate information regarding the disaster, provide safety and security personnel to anticipate any urgent response in the field. In the context 
of community's protection, community members entitle to get early warning of any disaster, for minimizing their direct exposure to the disaster. They also entitle to be evacuated and temporarily posted at the evacuation center. During the disaster, the community has the right to access health service, fast response logistics, and meals in the evacuation center. Mobilization from the settlement to an evacuation center is also be provided for the disaster victims.

Based on those regulations in Indonesia, we see that the Indonesian government have tried to protect Indonesian people who exposed to disasters. Even, efforts to minimize disasters' harmful effects have also be done by providing early warnings; constructing better infrastructures, which are suitable with potential disasters in each specific area, providing budget and task force to manage the disaster, etc.

\section{Contractual obligation within disaster}

In contract law, disaster will be considered as force majeure. This terminology is referring to circumstances beyond the control of the parties, were intended to deal with unforeseen acts of God or of governments and regulatory authorities. More recently, the force majeure clauses have been drafted to cover a wider range of circumstances that might impact on the commercial interests of the parties to the contract. [7] Based on this definition, keywords of force majeure are circumstances beyond the control of the parties and unforeseen acts of God. It means, the circumstances are unavoidable, and it originates harmful conditions for the affected parties. Therefore, the parties in the contract must govern legal consequences arisen by this condition.

Article 1245 Book of Civil Law regulates any party who fails to perform his/her obligation in a contract does not have to pay any damage or interest if the cause of that failure is force majeure. It means force majeure is a specific reason to eliminate any obligation arisen from a contract. To make a contract is easily applicable, what is the real meaning of the force majeure must be sufficiently described by the parties. Some components must be clearly indicated at this clause, i.e.: [8]

a. How broad the triggering events should be.

- Most common triggering events in majority contracts will cover acts of God (which are usually linked to disaster, such as landslide, earthquake, storm, tornado, flood, etc.

- Disturbance to security and community stability, such as terrorism, revolution, civil war, military actions, sabotage, rebellion, etc.

- Health disturbance such as the epidemic, quarantine.

- Change of governmental policy or decision of authority, etc.

Those circumstances are mostly addressed as the most common triggering events in contracts.

b. What impact must those events have on the party who invokes the clause? The parties are free to manage what are legal liabilities, which could be provided by the failing party after the triggering events. Nevertheless, it is almost a universal rule in civil law system (in which Indonesia is included in) that the failing party does not have to pay any damage or interest, because the obligation is naturally impossible to be performed. It means the position of the contracting parties will be restored as if the contract has never been concluded.

In fact, there are many problems to implement that principle, when a catastrophe had happened. Even though the disaster can be used as a reason to clear an obligation, still many parties had difficulties to safeguard such a protection directly after the disaster. The problem is before the failing party can avoid his obligation, he/she must prove that the event is part of triggering events in the force majeure clause. If there is no agreement about that issue between the parties, they have to settle the case using litigation or adjudication. This procedure takes time. In this case, before a final and binding court decision or arbitral award, the parties still must fulfill their obligations, which is still possible to be done.

A good example of its problem is in Lapindo mud flooding in Porong - East Java. The flood had happened in settlement areas. On 29 May 2006, hot mud had squirted in that area. [9] Some geology claimed that this flood had occurred because of exploration and drilling activities by PT. Lapindo Brantas Inc. [10] Nevertheless, other experts mentioned the cause of the flood was Yogyakarta (Central Java) earthquake on 27 May 2006. [11] This debate is very important to be solved because the category of this event is very important for many stakeholders.

Many suburbs are in that area, including housing complexes. Many people have bought their houses using the installment scheme of payment. After the flood, their houses had been buried by the mud. They could not live at those houses anymore since the houses were not existing anymore. The question is: should the debtor (in this case is the disaster victims) pay the rest of the installment until it had been completed? Or should the creditors take the risk and did not get further installment? Who must be responsible for any damage from the disaster?

We must certainly know the legal classification of the mud flood. If it was considered as a drilling malpractice, the responsible party was indeed PT. Lapindo Brantas Inc. Nevertheless, if it was classified as a natural disaster, all recovery cost must be provided from the state or regional budget. Consequently, it is very important to know the legal nature of that mud flood.

Based on President Regulation No. 14 year 2007, President Regulation No. 48 year 2008, President Regulation No. 40 year 2009, President Regulation No. 68 year 2011 and President Regulation No. 37 year 2012, disaster response will be done based on a Map of Affected Area. There is a cost-sharing between PT. Lapindo Brantas Inc. and the government, i.e. if the disaster response is within the Map of Affected Area, the cost of disaster response will be paid by PT. Lapindo Brantas Inc. while if the response is outside the Map of Affected Area, cost of the response must be provided by 
the government of Republic of Indonesia's budget. Disaster response, in this case, will be done by purchasing the affected land for farming and housing from the disaster victims. Payment of the sale and purchase of the land must be paid within 2 years period. The disaster victims had been expected to be able to buy a new land to relocate their housing, farming or other purposes.

Additional to those President Regulations, there is article 9 paragraph (1) a Law No 15 year 2013 regarding Amendment of Law No. 19 year 2012 concerning State Income and Budget year 2013, which based on Supreme Court of Constitution Decision No 83/PUU-XI/2013, must be understood as 'With the power owned by the State, completion of the compensation for communities within the Map of Affected Area by the company [sic: PT. Lapindo Brantas Inc.] must be guaranteed and assured by the State.' Based on this Decision, the affected people within the Map of Affected Area will certainly receive compensation, even if PT. Lapindo Brantas Inc had drilling mal-practiced. It means that the disaster will be considered as an issue within the State responsibility. It has the right to force the company to pay the compensation, and if the State fails to do it, it must use the State budget to pay the compensation.

This Decision is actually fair for the affected communities because it protects the disaster victims from any detrimental effects caused by the disaster. Nevertheless, this Decision had been decided on 26 March 2014, while the disaster had happened on 29 May 2006. There is about 8 years lapse before the disaster victims got that legal certainty. The question is, before that Decision, what protection should be given to disaster victims? There is no guarantee that their obligation will be frozen until they got legal Decision.

Another question also arises. If a disaster is not widely affected many people, and there is no national disaster status is granted to that catastrophe, how does the law protect that disaster victim? If there is no court decision or regulation acknowledging the disaster status, how should the party (who must perform any obligation from a contract)?

A contract is formed based on an agreement of the parties. [12] If the contract has been formed validly, the contract will be mutually binding for the parties. [13] Thus, if the parties want to amend any content in the contract, that can be done based on their consensus. It includes if the party wants to give up on his/her rights from the contract. In the context of the disaster response, the victim can be freed from his/her obligation from the contract, if it is agreed to voluntarily by his/her counterpart. In contrary, if the counterpart does not want to leave off his/her entitlement; if the disaster victim who has to perform any obligation from the contract cannot perform his/her obligation because of a triggering event such as a natural disaster, the parties will be in a legal dispute. Even though based on the law, a natural disaster is considered as a force majeure, without the agreement from the counterpart, the obliging party must prove that the triggering event is a force majeure. Then, the parties must first settle their dispute before they can decide whether after the force majeure the obliging party still must perform his/her obligation. The process will take time.

Back to the mud flood disaster in Porong, after 2006 the obliged party must pay their housing installment payment, even when their house had been sinking. It could not be used, it did not have any value anymore. The land title has gone because of that disaster, yet it did not erase the debt that had been secured by a mortgage. [14] It means, as disaster victims, they had to pay the installment until it had been taken over by the State. Unfortunately, in many cases, disaster victim cannot afford that installment anymore. Since the flood had been decided as a natural disaster [15], compensation must be paid by the State.

\section{The role of ethics when Indonesian legal system fails to provide any protection for victims interest}

As it has been explained previously, there is a possibility that the Indonesian legal system fails to protect the interests of disaster victims. Some illustrations can be provided as follows:

a. A contract has obliged the disaster victim to perform a punctual payment for his loan agreement. He fails to do it because all of his assets have gone because of the disaster.

b. A flood has never been declared as a national disaster. Yet, the house of one family has been swiped by the flood and that family lose their assets. There is no clear legal protection for the victim of such the disaster.

It is not clear what is the minimum number of people who must be harmed, or the minimum amount of property that must be damaged, in order for something to qualify as a disaster. [16] In this case, if there are victims who cannot afford their proper living. Therefore, legal protection sometimes cannot completely safeguard the interests of the disaster victims. It is important to secure the proper living of the disaster victims, even if or moreover when the law cannot provide legal protection. In this case, we have to find alternative solutions to help them. One relevant theory is offered by Ronald Dworkin, i.e. a concept of law as integrity. It claimed a fundamental virtue of how we should take the law as a political morality, which flourished and deliberated in our community. Here, Dworkin's theory of law will be used to evaluate the positivistic-legalistic orientation which has been commonly accepted in Indonesian legal developmental history. This theory contains and respects the intrinsic cultural-moral values. [17] Based on this theory, the concept of law should be understood and administered as a moral integrity. In a certain legal case, the essence of law was a triumph of fundamental individual human rights discovered by the judges. [18]

Back to disaster response and protection for disaster victims, we have to apply the living law, which covers not only regulations but also morality and ethics. It must also cover human rights ideals in this issue. The highest morality and ethics in this disaster response should be 
expressed by safeguarding the interests of the disaster victims as long as:

- They have no capacity to provide their own needs, and

- The written law does not provide sufficient legal certainty to defend their basic needs.

Hence, the merely positivistic approach is not sufficient to respond to the disaster.

How the community must response the disaster should be determined based on the characteristic of the disaster's impact on them. In this issue, human loss parameter must be applied for extending the meaning of written law under the context of ethics and morality. The application of human loss parameter can be described as follow: [19]

- First, we have to understand what the main causes of human loss during the disaster are;

- Second, we have to identify what the critical components of each human loss cause category;

- Third, we have to know how each category could have the adaptability to adjust itself in times of disaster;

- Finally, we have to analyze which response could be expected will lead us to disaster mitigation guidelines that focus on problem areas to have an easier disaster recovery.

The human loss parameter can be used to determine the strategy to response the disaster and further to mitigate it.

Additionally, in the absence of legal protection for disaster victims, the government must actively provide more protections, based on its discretionary decision. It is not an ideal solution, but it must be done because recently Indonesian's regulation does not yet cover protection for disaster victims related to private law issues. It will be helpful if we can share potential roles of the government to respond to the disaster, which has been designed based on ethics and will be used to measure its discretionary decision. It will cover: [20]

- Facilitating the receipt of private compensation for the consequences of a disaster. This support is very crucial to enable disaster victims to faster recovery from the impact of the disaster.

- Assuring insurance availability for disaster victims when the market fails to do so. In this case, the government must establish a social security protection, which will protect the insured party from disaster risks.

- Providing victim compensation when the government should have prevented the disaster. As an example, if a relocation of the affected party is necessary for avoiding them from any dangerous disturbance of a disaster.

- Providing victim compensation as an alternative to tort recovery. This role had been done in the case of the Lapindo mud flood disaster. PT. Lapindo Brantas had been ordered by President Regulations to pay damages arisen from the mud flood within the Map of Affected Area. These President Regulations had safeguarded the rights of disaster victims to receive compensation from a tort actor.
- Providing victim assistance to overwhelmed communities for reasons of altruism and national solidarity. This is an effort to involve all community members to help each other by providing any financial support using a fundraising, logistics, temporary shelter, and other assistance, to make the disaster victims have more capacity to adapt to the disaster. This creates a higher sense of togetherness among the community during a disaster.

Those roles are important to be projected because those are options to correct incompleteness of Indonesia legal system related to disaster management.

\section{Conclusions}

Disaster management is part of the fundamental right in Indonesia, because article $28 \mathrm{~A}$ of Indonesian Constitution 1945 , the $4^{\text {th }}$ Amendment has recognized that everyone has the right to live and to defend his/her existence. Article $28 \mathrm{C}$ also emphasizes the right of everyone to fulfill his/her basic needs. Those two articles are important provisions to set the platform to protect every disaster victims. Specifically, those two provisions have been elaborated in the Law concerning Disaster Management. It imposes a duty on the State to adopt proper disaster management policies to ensure sustainable development of the nation.

A review of the legal issues has arisen out the flaw of Indonesian legal system, especially related to protection for disaster victims in the field of contract law or law on obligations. In the field of disaster management, disaster victims have been quite protected, because they have the right to access health service, fast response logistics and meals in the evacuation centre, mobilization from the settlement to an evacuation centre and return to their settlement, and to be relocated, if their original place cannot be used anymore. Some rights during a disaster response are also regulated. Nevertheless, in the field of contractual law, there is lack of protection except their right to claim damages if the disaster had happened because of a wrong construction by the constructor of the disaster victims' settlement.

Disaster response in the field of contractual law is done only by placing disaster as a triggering event of force majeure. Consequently, there is no payment or interest can be imposed for any failure to perform of any obligation arisen from the contract. However, if the parties cannot voluntarily agree to freeze the contractual obligation after a force majeure, while the obliging party (who is a disaster victim) is the incapacity to perform his/her obligation, the parties will be in a legal dispute. In this particular part, in the future, the law should provide additional legal protection for disaster victims by imposing the direct power of the force majeure to freeze any obligation arisen from the affected contract. Furthermore, the government must have the national and regional budget to support the disaster victims to recover from their catastrophe.

Since the Indonesian legal system still does not cover any protection for disaster victims in the field of contractual law, this weakness must be compensated by 
providing more active roles from the government to support disaster victims. It will be done based on the discretionary decision of the government.

\section{References}

1. Yetta Gurtner, Alison Cottrell, David King, Pre, and Rapid: Community Impact Assessment for Disaster Recovery. Centre for Disaster Study, James Cook University, (2011).

2. Paul Chynoweth, Legal Research. Blackwell Publishing Ltd, 2008.

3. Arthurs, H.W. Law and Learning: Report to the Social Sciences and Humanities Research Council of Canada by the Consultative Group on Research and Education in Law, Information Division. Social Sciences and Humanities Research Council of Canada, Ottawa, (1983)

4. Theresia Anita Christiani, Normative and Empirical Research Study: Their Usefulness and Relevance in the Study of Law as an Object. Procedia - Social and Behavioral Sciences 219 ( 2016 ) $201-207$.

5. Government Regulation No. 22 year 2008 concerning Disaster Management Budgeting.

6. Chief of Indonesian Police Regulation No. 17 year 2009 concerning Disaster Management.

7. Damian Mc. Nair, Force Majeure Clauses. DLA Piper, Asia Pacific Project Update, 2011.

8. Michael P Theroux And April D Grosse, Force Majeure in Canadian Law. Alberta Law Review, 2011, (29:2).

9. Anton Novenanto, Seeing the Lapindo Case as a Social Disaster. Center for Religious and CrossCultural Studies (CRCS)-Universitas Gadjah Mada, Institute of Cultural Anthropology and Development Sociology (CA/DS)-Leiden University, (2009).

10. Davies, R, Swarbrick, RE, Evans, RJ \& Huuse, M, Birth of a mud volcano: East Java. GSA Today, (29 May 2007).

11. Mazzini, A, Svensen, H, Akhmanov, GG, Aloisi, G, Planke, S, Malthe-Sorenssen, A \& Istandi, B, Triggering and dynamic evolution of the LUSI mud volcano, Indonesia. Earth and Planetary Science Letters 261:375 -88.

12. Rosa Agustina, Suharnoko, Hans Niewenhuis, Jaap Hijma, (Law of Obligations). Library Larasan, (2012).(In Indonesia)

13. Harry Purwanto, Existence of Pacta Principle Sunt Servanda in the International Agreement. Pulpit Hukum, Volume 1, Number 1, (February 2009), pp. 155-170. .(In Indonesia)

14. Nur Amaliah Ranie, Legal Protection of Creditors in Credit Agreements with Guaranteed Underwriting Rights whose Objects Affected by Lapindo Mudflow. Notary Study Program, Diponegoro University Graduate Program, (2008). .(In Indonesia)

15. Muhtaro Ludfi Al Ansori, Sociological Juridical Review of Completion of Sengkete Pollution and Environmental Damage (Case Study of Decision No. 103 / K / TUN / 2010, No. 2710 / K.Pdt / 2008, No. 11 / Pid / 2009 / PT .TK, Mediation between PT CSI and the Rejoso Pasuruan Community, Muhamadyah University Graduate Program, Malang. .(In Indonesia)

16. Stephen D. Sugarman, Roles of Government in Compensating Disaster Victims. The Berkeley Electronic Press, (2006).

17. Ida Susanti and Sebastian Tanius, Supremacy of Ethics, When National Law and Customary Law or Islamic Law are Collided. Advances in Social Science, Education and Humanities Research, volume 84, (2017).

18. Ronald Dworkin, "From Justice in Robes to Justice for Hedgehogs. Lecture delivered at the Instituto de Investigaciones Jurídicas of Universidad Nacional Autónoma de México" Problema. Anuario de Filosofia y Teoria del Derecho, núm. 9, (2015)

19. $13^{\text {th }}$ World Conference of Earthquake Engineering, Paper No. 1227, A Study on Community Disaster Response: a Way toward Vulnerability Reduction. Vancouver - Canada, (2004)

20. Stephen D. Sugarman, Roles of Government in Compensating Disaster Victims. The Berkeley Electronic Press, (2006) 